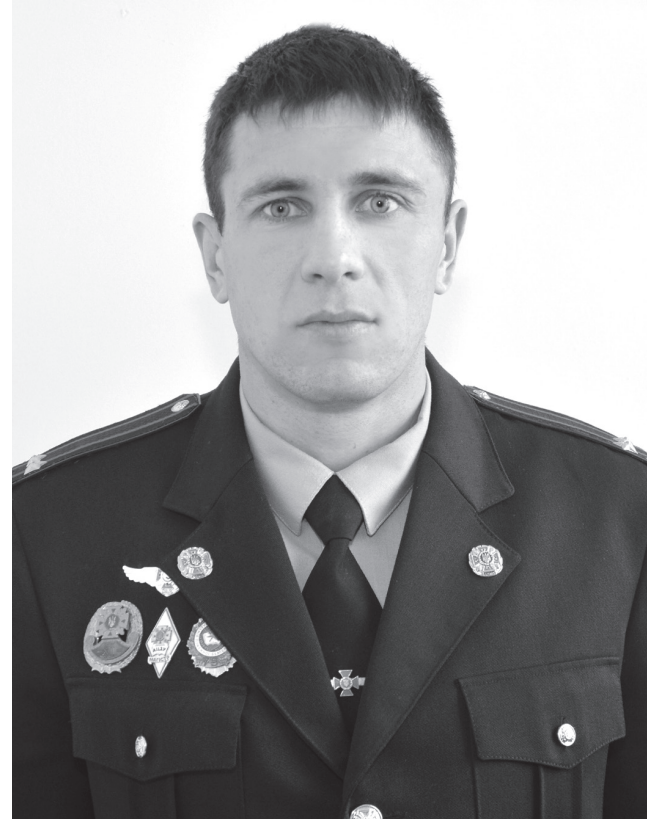

Vavrenyuk Sergey Anatolievich, PhD in Public Administration, Doctoral candidate of Educational, Scientific and Production Center of the National University of Civil Defense of Ukraine, 61023, Kharkiv, Str.Chernyshevska,94,tel.: (057) 7003171,e-mail: sergei-vavrenyuk@nuczu.edu.ua

ORCID: 0000-0002-6396-9906

\title{
МОНІТОРИНГ ЯК ЗАСІБ ДОСЯГНЕННЯ ЯКОСТІ ВИЩОї ОСВІТИ УКРАЇНИ
}

Анотація. Розглянуто систему вищої освіти України: досягнення якості освіти та надання освітніх послуг вищими навчальними закладами. Важливим процесом для досягнення якості є моніторинг. Проаналізовано поняття та компоненти моніторингу як одного з інструментів управління системою вищої освіти на макро- та мікрорівні.

Визначено, що моніторингові технології в системі освіти мають великі можливості, однак недостатньо враховано його безпосередній вплив на ефективність якості освіти.

Окреслено напрями для досягнення основних параметрів високої якості освіти в навчальних закладах за допомогою моніторингу, який здатний забезпечити комплексний та системний характер дослідження. Детально вивчено види і завдання навчального моніторингу, організаційно-методичні підходи до його проведення, а також принципи і етапи. 
Визначено, що моніторинг не є універсальним засобом, але його ефективна організація, що відповідатиме існуючим умовам, і адекватне застосування його результатів сприятиме суттєвому підвищенню якості освітнього процесу.

Розкрито зв'язок моніторингу освіти і процесу управління системою вищої освіти, а також схожість і відмінність між процесом моніторингу, контролем освіти і навчальних закладів.

Запропоновано шляхи вирішення можливих проблем при впровадженні процесу моніторингу при оцінюванні якості освіти. При цьому визначено необхідність проведення комплексної оцінки, яка сприятиме більш ефективному проведенню моніторингу, тим самим підвищуючи якість освіти.

Ключові слова: моніторинг, якість вищої освіти, освітні послуги, вища освіта.

\section{МОНИТОРИНГ КАК СРЕДСТВО ДОСТИЖЕНИЯ КАЧЕСТВА ВЫСШЕГО ОБРАЗОВАНИЯ УКРАИНЫ}

Аннотация. Рассмотрена одна из актуальных тем в системе высшего образования Украины - достижение качества образования и предоставление образовательных услуг высшими учебными заведениями. Важным процессом для достижения качества является мониторинг. Проанализированы понятия и компоненты мониторинга одного из инструментов управления системой высшего образования на макро- и микроуровне.

Определено, что мониторинговые технологии в системе образования имеют большие возможности, однако недостаточно учтено его непосредственное влияние на эффективность качества образования.

Очерчены направления для достижения основных параметров высокого качества образования в учебных заведениях с помощью мониторинга, который способен обеспечить комплексный и системный характер исследования. Подробно изучены виды и задачи учебного мониторинга, организационнометодические подходы к его проведению, а также его принципы и этапы.

Определено, что мониторинг не выступает как универсальное средство, но его эффективная организация, которая будет отвечать существующим условиям, и адекватное применение его результатов способствует существенному повышению качества образовательного процесса.

Раскрыта связь мониторинга образования и процесса управления системой высшего образования, а также сходства и отличия между процессом мониторинга, контролем образования и учебных заведений.

Предложены пути решения возможных проблем при внедрении процесса мониторинга в оценку качества образования. При этом указывается необходимость проведения комплексной оценки, которая будет способствовать более эффективному проведению мониторинга, тем самым повышая качество образования.

Ключевые слова: мониторинг, качество высшего образования, образовательные услуги, высшее образование. 


\section{MONITORING AS A MEANS OF ACHIEVING THE QUALITY OF HIGHER EDUCATION IN UKRAINE}

Abstract. This article is devoted to one of the topical issues in the system of higher education in Ukraine - the achievement of quality education and the provision of educational services by higher education institutions. An important process for achieving quality is monitoring. Therefore, the author presents an analysis of the concept and components of monitoring, which is one of the tools for managing the higher education system both at the macro and micro levels.

The purpose of the article is to find current problems of organizing and monitoring the quality of education in the system of higher education in Ukraine, as well as analysis of the directions of its use.

In the course of the analysis, the author determines that monitoring technologies in the education system have great opportunities, but his direct impact on the effectiveness of the quality of education is not sufficiently taken into account.

In addition, the author points out the directions for achieving the main limits of the high quality of education in educational institutions through monitoring, which is capable of providing a comprehensive and systematic nature of the study. The types and goals of the training monitoring, organizational and methodological approaches to its implementation, as well as the principles and stages of monitoring were studied in detail.

It is determined that monitoring does not act as a universal tool, but its effective organization, which will meet the existing conditions, and the adequate application of its results give to a significant improvement in the quality of the educational process. The article reveals the relationship between the monitoring of education and the process of managing the higher education system, examines the similarities and differences between the monitoring and control of education and educational institutions.

In conclusion, the author gives solutions to possible problems in the implementation of the monitoring process in assessing the quality of education. At the same time, it points to the need for an integrated assessment, which will help more effective monitoring, thereby improving the quality of education.

Keywords: monitoring, quality of higher education, educational services, higher education.

Постановка проблеми. Одним 3 питань, що на сьогодні недостатньо вирішене, є створення системи управління якістю в закладі вищої освіти, тому що відповідно до умов створення єдиного європейського освітнього простору саме навчаль- ний заклад відповідає за якість освітніх послуг. Головним чином, особливу актуальність становить проблема оцінювання якості навчального процесу за допомогою моніторингу ефективності освітньої діяльності закладу вищої освіти. Для 
сучасної системи освіти проблема якості набуває найбільш актуального значення. Поряд з цим якість освіти насамперед визначає характеристики результату навчання у закладі вищої освіти, фіксує зміни в системі професійних знань та умінь тих, хто навчається під час проходження усіх етапів освітнього процесу, починаючи від початкового та закінчуючи кінцевим рівнем вивчення навчальної дисципліни. Варто зазначити, що проблема якості освіти нерозривно пов’язана з проблемою моніторингових досліджень.

Аналіз останніх публікацій за проблематикою. Розгляду проблеми підвищення якості вищої освіти приділяється значна увага. Так, G. Shrikanthan та інші вказують на необхідність розробки цілісної моделі якості вищої освіти [1]. Різні аспекти, які впливають на якість освіти, вивчають Е. Van Kemenade та інші [2]. Приділено увагу також різним процесам, які застосовують при оцінюванні якості освіти та моніторингу як інструменту для цього. J. Lyotard наголошує, що освіта є інституціоналізованим, тобто формальним процесом, на основі якого суспільство передає цінності, вміння й знання від однієї людини, групи, спільноти - іншим [3].

Якщо розглядати такі поняття, як “якість вищої освіти" та "моніторинг якості освіти”, слід відмітити, що вони не знайшли свого кінцевого визначення у педагогічній теорії та практиці. Про це свідчать результати теоретичного аналізу науково-педагогічних, методичних, публіцистичних та інформаційних джерел інформації, де серед практиків та теоретиків не спостерігається однієї єдиної думки відносно тлумачення “моніторинг якості освіти”.

Шоб розкрити сутність визначення “моніторинг якості освіти”, на наш погляд, потрібно визначити поняття “якість освіти” в контексті вищої освіти. Це дасть можливість встановити взаємозв’язок згаданих понять, а також розробити раціональну та всебічну систему показників і критеріїв, щоб можна було визначати якість вищої освіти як об'єкт оцінки, оскільки вона відображатиме всі i.. аспекти та складові.

Постановка завдання. Метою статті є аналіз поняття моніторингу якості освіти, а також основних методів і напрямів використання процесу моніторингу для розвитку вищої освіти України.

\section{Виклад основного матеріалу.} Якість освітньої діяльності виступає як набір характеристик системи вищої освіти та їі складових, яка визначає i спроможність задовольняти встановлені та передбачені потреби окремої особи та суспільства загалом. На сьогодні ми бачимо, що разом $з$ утворенням та розбудовою європейського освітнього простору стають актуальними питання якості вищої освіти. Однак, на думку деяких спеціалістів, недостатньо чітко сформовано позиції європейського освітнього простору з питань забезпечення якості вищої освіти в тексті Болонської декларації.

Для визначення якості освітніх послуг, а також роботи самої системи управління якістю в закладі вищої освіти, проводять моніторингові дослідження. Моніторинг забезпечує управління інформацією. Як- 
що студенти проводять оцінювання організації навчального процесу, діяльності викладачів, то сам факт здійснення моніторингу забезпечує управлінську діяльність. Знаючи результати, викладачі коригують свою діяльність відповідно до тих критеріїв, за яким проводилося оцінювання [4].

Саме тому, на наш погляд, важливим моментом у плані визначення якості освіти навчального закладу стає проведення моніторингу. Це призводить до того, що постає потреба у розкритті сутності поняття “моніторинг якості вищої освіти”.

У результаті проведення теоретичного аналізу науково-педагогічних джерел потрібно зазначити про достатню різноманітність підходів до сутності поняття "моніторинг якості освіти”. Розуміння слова “моніторинг” має ряд визначень та використовується не тільки у сфері освіти.

Зокрема, в педагогічній літератуpi до слова "моніторинг” застосовуються такі синоніми, як “контроль” та “діагностика”. В результаті аналізу можна зробити висновок, що потрібно розрізняти ці поняття [5].

Ряд вчених розглядають контроль, як одну з функцій управління, яка спрямована на виконання трьох завдань: виявлення відхилень фактичних результатів управління від передбачених, вияснення причин розходження цілі та результатів управління та визначення змісту регулюючої діяльності задля зменшення виникаючих відхилень. Коли контроль є складовою управлінського циклу, то він спрямований на організацію реалізації плану роботи та йо- го цілі. В результаті контроль має ситуаційний характер та є нетривалим у часовому просторі. Проглядається зв'язок контролю з мікроелементами освітньої системи, коли моніторинг зв'язаний $з$ функціонуванням усієї системи. Перед плануванням та прийняттям рішення передує моніторинг [6].

Варто зауважити, що моніторинг, на наш погляд, дещо ширше поняття порівняно з контролем, яке охоплює як діагностичні дослідження, так i контрольні вимірювання та аналіз. При діагностиці ми з'ясовуємо усі обставини руху освітнього процесу та визначаємо його результати. А при контролі більше уваги звертається на об'єкт у стані стабільного функціонування. Загалом виокремлюють два основних види контролю: контроль результатів, тобто, що було зроблено із запланованого, що залишилося невиконаним та які результати були отримані, й контроль процесу, який дає змогу виявляти можливі відхилення від норми діяльності та рівень раціональності діяльності та 1̄i часові характеристики.

Підсумовуючи сказане, зазначимо, що завдяки моніторингу можна досягти оптимального поєднання контролю та результатів процесу. Окрім цього, моніторинг охоплює аналіз, діагностику, нормування, програмування, конструювання та проблематизацію. За допомогою моніторингу вивчається не тільки процес та його результат, а й створюється проект нової діяльності на сучасному етапі розвитку системи вищої освіти та значно розширюються можливості закладів вищої освіти. 
Фактично моніторинг ототожнюється із системою збору та аналізу відповідної інформації, при цьому важливо розуміти вимоги, які висуваються до інформації. Моніторинг забезпечує дослідження, що спрямовані на основні параметри навчального закладу. При проведені моніторингових досліджень потрібно зберігати результати та накопичувати банк даних. Однак це не можливо здійснити без інформаційного забезпечення, тому розроблення i застосування інформаційної системи потрібно розглядати як складову основного завдання впровадження системи якості закладу вищої освіти [7].

Основним завданням інформаційної системи є супровід системи якості, здійснення підвищення ефективності та результативності їі функціонування, щоб забезпечити високий рівень задоволеності усіх зацікавлених сторін у діяльності закладу вищої освіти. Така система позитивно впливає на покращення як навчально-виховних, так і фінансово-економічних показників. Для впровадження інформаційної системи потрібна підтримка вищого керівництва та відповідні ресурси закладу вищої освіти. На сьогодні в нашій державі застосовується універсальна модель інформаційної системи супроводження системи якості навчальних закладів, вона $€$ трирівнева та складається із системи управління документацією, системи управління базою даних і системи управління знаннями.

Щоб підтримувати систему моніторингу якості освіти потрібне чітке розмежування обов'язків та повно- важень. Спосіб розроблення та впровадження моніторингу якості освіти в навчальному закладі також можливо використовувати в організаціях по іншому профілю та виду діяльності, тому що організація має напрям на постійне удосконалення роду діяльності, забезпечення системного підходу, стимулювання впровадження інноваційних технологій й покращення рівня задоволення споживачів освітніх послуг.

На думку науковців, моніторинг спрямовується на досягнення основних параметрів навчального закладу та має статус дослідження, а не виступає засобом емпіричного збору матеріалів. Він забезпечує комплексний, системний характер та створюе умови для планування. Щоб проводити моніторингові дослідження потрібно розробити методику, тобто визначити необхідні методи та інструментарій, зокрема, опитувальні листи, анкети, бесіди, інтерв'ю [8].

Якщо повертатися до відмінностей між моніторингом та контролем, варто відзначити, що при моніторинговому дослідженні відбуваються повторення через визначений проміжок часу та досліджуються одні об'єкти. Одночасно потрібно розробляти концепцію, яка має містити стратегічну ціль, оперативні цілі, дослідницьке завдання та проблеми з кількох питань і відповідей, які можна отримати за допомогою розроблених методів. Тому можна стверджувати, що моніторинг потрібен для збору даних про окремий об'єкт дослідження та повторюється з часом.

Також слід наголосити на взаємозв'язку моніторингу з культурою оцінювання, відповідність його про- 
цедур культурі оцінювання, тому що це є важливою умовою ефективності моніторингу.

Культуру оцінювання можна схарактеризувати наступними показниками:

- наявність чітких критеріїв оцінювання;

• розроблення процедури оцінювання;

• присутність кваліфікованих експертів;

- чіткі форми фіксації інформації під час моніторингу;

- розроблені часові характеристики оцінювання;

- чіткий зв’язок оцінювання 3 прийняттям рішення.

Під час моніторингу відбувається безперервне або періодичне спостереження за навколишнім середовищем для того, щоб запобігти небажаному відхиленню за основними досліджуваними параметрами. Моніторинг має систематичний характер спостереження та є превентивним.

Під освітнім моніторингом ми можемо розуміти систему організації збору, збереження, обробки та розповсюдження інформації про діяльність педагогічної системи, яка забезпечує безперервне стеження за його станом та прогнозування розвитку. Якщо говорити про моніторинг у системі освіти, слід зауважити, що це направлене організоване, цільове, системне спостереження за якістю освіти, яке дозволяє виявляти відхилення від державних стандартів та рівень задоволення освітніх потреб населення [9].

На наш погляд, моніторинг якості вищої освіти включає в себе регулярне, спеціально організоване систематизоване спостереження за якістю вищої освіти, тобто освітніми послугами, які надає заклад вищої освіти, а також за діяльністю систем управління якістю в даному вищому закладі.

Після проведеного теоретичного аналізу наукових та педагогічних джерел інформації можна визначити такі функції моніторингу, як: діагностична, інформаційна, аналітико-оціночна, стимулююча, мотиваційна, контролююча, прогностична, корекційна.

Залежно від моніторингових процедур визначається і тип моніторингу, що зумовлений завданнями, цілями, різного роду процедурами та смисловими особливостями.

Виокремлюють такі типи моніторингу:

- стратегічний, тактичний та оперативний, відповідно до масштабу цілей та завдань освітньої справи;

- вхідний або відбірковий, навчальний або перемінний, вихідний або підсумковий, залежно від етапів навчання;

- ретроспективний, попереджувальний, текучий, порівняно $з$ тимчасовим показником;

- разовий, періодичний, систематичний, відповідно до частоти процедур;

- локальний, вибірковий, суцільний, якщо враховувати масштаб об'єкта спостереження;

- індивідуальний, груповий, фронтальний, залежно від організаційних форм;

- зовнішній або соціальний, взаємоконтроль, самоаналіз, якщо задіяні аналітичні процедури в контексті суб'єкт-об'єктивних відносин; 
- стандартний, нестандартний, матричний, коли застосовується інструментарій;

- локальний, модульний, системний, під час масштабної інноваційної діяльності.

Зауважимо, що мета проведення моніторингу полягає у підвищенні ефективності функціонування системи, особливо ефективності діяльності закладу вищої освіти, завдяки підвищенню якості освітніх послуг, що надає заклад.

Відповідно до цього метою освітнього моніторингу є: відстеження динаміки якості освітніх послуг та ефективності управління якістю освіти у навчальному закладі. Залежно від означеної мети можуть бути сформульовані наступні завдання:

- постійний нагляд за станом вищої освіти та отримання оперативної інформацї̈ щодо неї;

- своєчасне виявлення змін та відхилень, які можуть вникати в системі вищої освіти та факторів, що викликають ці зміни;

- попередження негативних тенденцій;

- здійснення прогнозування розвитку основних процесів у закладі вищої освіти;

- оцінювання повноти та ефективності реалізації методичного забезпечення освіти.

До основних принципів освітнього моніторингу потрібно віднести: принцип науковості, професійної відповідності, безперервності, цілісності. Щоб проводити освітній моніторинг потрібно дотримуватися загальних та організаційно-методичних вимог. Так, серед загальних вимог вирізня- ють систематичність, об’єктивність, точність, достатність, повноту, надійність, оптимальність, структурованість, узагальнення, оперативність, доступність, облік психолого-педагогічних особливостей, гуманістичну направленість [10].

Якщо застосовувати організаційно-методичні вимоги до проведення моніторингу, потрібно звертати увагу на наступні:

- моніторинг має проводитися 3 обмеженим та постійним набором i формою показників протягом встановленого періоду;

- показники повинні фіксувати феномени освітнього процесу, які вже достатньо вивчені в науковому плані та адекватно можуть відображати рівень якості освіти;

- показники мають носити характер оцінювання;

- не рідше одного разу на рік потрібно коригувати набір показників, які використовуються;

- при результатах моніторингу не можливі репресивні міри, а тільки характер стимулювання відносно педагогів до своєї професійної діяльності.

Щодо підходів проведення моніторингу, варто зауважити, що не існує єдиного підходу до кількості та назв його етапів. У педагогічній літературі визначено такі етапи:

- підготовчий, тобто з’ясування мети, визначення об'єкта, встановлення терміну проведення спостереження, співбесіди, тестування, анкетування, контроль діагностичних зрізів;

- аналітичний, який включає в себе аналіз та систематизацію отриманої інформації, розроблення реко- 
мендацій та пропозицій на наступний період, формування висновків.

Деякі вчені виокремлюють такі етапи моніторингового процесу:

- нормативно-встановлений, під час якого визначають мету та завдання педагогічного моніторингу, основні показники та критерії, засоби досягнення реальних показників дослідницького об'єкта;

- аналітичний, до якого входить збір інформації за допомогою підібраних методик, кількісна та якісна обробка отриманих результатів, вироблення педагогічного діагнозу;

- діагностичний, що включає в себе аналіз результатів проведеної роботи, визначення реального рівня досягнень об'єкта моніторингу, порівняння його 3 нормативними показниками, відомості про результати організації та проведення моніторингу;

- прогностичний, передбачає прогнозування подальших тенденцій та можливості розвитку досліджуваного об’єкта, розробку плану педагогічних корекційних дій;

- діяльно-технологічний, що здійснює корекцію педагогічного процесу.

На нашу думку, саме такі етапи проведення моніторингу досить чітко описують процедуру проведення моніторингу.

Висновки та перспективи подальших досліджень. Підсумовуючи зазначене, варто сказати, що проблема якості освіти, а особливо вищої освіти, виникла у зв'язку 3 приєднанням нашої держави до європейської зони освіти. Стало відомо, що визначення якості вищої освіти пов'язане зі спеціальни- ми процедурами, створенням нових установ, метою яких має бути суспільна оцінка якості освітніх послуг, які будуть надаватися. На кожному освітньому рівні - національному, регіональному, рівні закладу вищої освіти, потрібно проводити системне та систематичне дослідження якості освітньої діяльності.

Таким чином, під час проведення аналізу теоретичного матеріалу було встановлено, що на сьогодні немає єдиного підходу до визначення дефініції “моніторинг якості освіти". Для реалізації задач моніторингу потрібно розробляти науково-практичні інструменти. Найбільш раціональними методами для вирішення таких задач є метод опитування, експертного оцінювання, спостереження, вивчення документації.

Серед показників якості освіти можна виділити університетський рівень, інститутський (факультетський) рівень та показники якості освіти кафедрального рівня. Структурованість роботи підрозділів закладу вищої освіти та ефективність системи управління мають складати основи оцінки якості роботи закладу взагалі. Оцінка якості навчально-виховного процесу повинна визначати якість навчальних програм, планів, розкладу занять, склад науково-педагогічних працівників та студентів.

При оцінюванні якості науково-дослідної діяльності потрібно звертати увагу на якісний склад науково-дослідних працівників, якісне використання фондів, що виділяються на дослідження.

Для визначення комплексної оцінки якості освітніх послуг потрібно враховувати думку трьох сто- 
рін: студентів, молодих випускників та працедавців, що будуть безпосередніми керівниками. Підсумок комплексного оцінювання становитиме розрахунок інтегрального показника, тобто рівня якості освітніх послуг, що вираховуватиметься як корінь третього ступеня з трьох показників, які відображають незалежну оцінку безпосередніх споживачів специфічної продукції.

\section{СПИСОК ВИКОРИСТАНИХ ДЖЕРЕЛ}

1. Srikanthan G., Dalrymple J. F. Developing a holistic model for quality in higher education / / Quality in Higher Education, 2002. Vol. 8 (3). P. 215-224.

2. Van Kemenade E., Pupius M., Hardjono $T$. W. More value to defining quality // Quality in Higher Education, 2008. Vol. 14 (2). Pp. 175-185.

3. Lyotard J., Bennington G. The postmodern condition: A report on knowledge. Minneapolis: University of Minnesota Press, 1984. 108 p.

4. Хильченко Л. Н. Внутренняя система оценки качества образования в университете: веяние времени или острая необходимость? // Coвременные научные исследования и инновации. 2014. № 11-3 (43). С. 131-136.

5. Буркіна Н. С., Лукіна Т. О. Моніторинг у системі загальноосвітньої підготовки // Освіта України. 2001. № 8. С. 5.

6. Вавренюк C.A. Підходи та інноваційні технології в освітньому просторі / С. А. Вавренюк // Збірник матеріалів XIV Міжнародної конференції "Стратегія якості у промисловості і освіті”, 4-7 червня 2018 р., Варна, Болгарія. С. 151-154.
7. Моніторинг стандартів освіти / за ред. Альберта Тайджмана і Т. Невілла Послтвейна. Л.: Літопис, 2003. $328 \mathrm{c}$.

8. Моніторинг якості освіти: світові досягнення та українські перспективи / за заг. ред. О. І. Локшиної. К.: K.I.C., 2004. 128 c.

9. Вавренюк С. А. Государственное регулирование реформирования высшего образования Украины на современном этапе / C. А. Вавренюк // EAST JOURNAL OF SECURITY STUDIES vol. 2/2. Наук. журн. "Східний часопис безпекових студій”, 2018. С. 15-24.

10. Домбровська С. М. Якість освіти як одна з запорук вдалого державного реформування вищої школи України / С. М. Домбровська // Актуальні проблеми держ. упр. 2011. № 1. C. 149-154.

\section{REFERENCES}

1. Srikanthan G., Dalrymple J. F. (2002). Developing a holistic model for quality in higher education. Quality in Higher Education. Vol. 8 (3). P. 215224.

2. Van Kemenade E., Pupius M., Hardjono T. W. (2008). More value to defining quality. Quality in Higher Education. Vol. 14 (2). P. 175-185.

3. Lyotard J., Bennington G. (1984). The postmodern condition: A report on knowledge. Minneapolis: University of Minnesota Press.

4. Khilchenko L. N. (2014). Vnutrennyaya sistema ocenki kachestva obrazovaniya $\mathrm{v}$ universitete_veyanie vremeni ili ostraya neobhodimost [The internal system for assessing the quality of education at the university: the trend of time or the urgent need?]. Modern scientific research and innovations. 11-3 (43). P. 131136. 
5. Burkina N. S., Lukina T. O. (2001). Monitoring u sistemi zagalnoosvitnoyi pidgotovki [Monitoring in the system of general education]. Education of Ukraine. 8. P. 5-9.

6. Vavrenyuk S. A. (2018). Pidhodi ta innovacijni tehnologiyi v osvitnomu prostori [Approaches and innovative technologies in the educational space], Collection of materials of the XIV International Conference "Quality Strategy in Industry and Education", June 4-7, 2018. Varna, Bulgaria. P. 151-154.

7. Albert Tajjman and T. Neville Postwine (2003). Monitoring standartiv osviti [Monitoring of Educational Standards]. Lviv: Litopis, Ukraine.

8. Lokshina O. I. (2004). Monitoring yakosti osviti: svitovi dosyagnennya ta ukrayinski perspektivi [Monitoring the quality of education: world achievements and Ukrainian perspectives], Kyiv, Ukraine.

9. Vavrenyuk, S. (2018). Gosudarstvennoe regulirovanie reformirovaniya vysshego obrazovaniya Ukrainy na sovremennom etape [State regulation of the reform of higher education in Ukraine at the present stage]. Est journal of security studies: Sciences. Journal. Vip. 2 (12). P. 15-24.

10. Dombrozskaya S. N. (2011). Yakist osviti yak odna z zaporuk vdalogo derzhavnogo reformuvannya vishoyi shkoli Ukrayini [The quality of education as one of the pillars of a successful state reform of higher education in Ukraine]. Actual problems of public administration. 1. P. 149-154. 